\title{
MODEL FUNGSI PENGAWASAN OLEH PENGADILAN TATA USAHA NEGARA SEBAGAI UPAYA MENUJU TATA KELOLA PEMERINTAHAN YANG BAIK*
}

\author{
Aju Putrijanti**, Lapon T.Leonard ${ }^{* * *}$ dan Kartika Widya Utama***** \\ Hukum Acara Tata Usaha Negara, Fakultas Hukum, Universitas Diponegoro, Jl. Prof Soedarto,
} Tembalang, Semarang, 50275

\begin{abstract}
Administrative Court is one of the implementation of judiciary system in Indonesia. Act No. 30 Year 2014 about Government Administration is the material law to administrative procedural law and as a legal basic for government to implement their duties The aims of this research are to know the Administrative Court's function in governance, the relationship between court's verdict and good governance, and to develop the monitoring model by the Court. This research is use empirical juridis method. The novelty is to know the monitoring model by Administrative Court against government's decree based on the Act No 30 Year 2014 of Governance Administration.
\end{abstract}

Keywords: administrative court, government adminisitration; good governance.

\section{Intisari}

Pengadilan Tata Usaha Negara adalah pelaksana kekuasaan kehakiman di Indonesia. Disahkannya UU Nomor 30 Tahun 2014 tentang Administrasi Pemerintahan sebagai sumber hukum materiil terhadap hukum acara peradilan tata usaha negara. Penelitian ini bertujuan untuk mengetahui pelaksanaan fungsi pengawasan oleh PTUN dalam pengembangan kualitas tata kelola pemerintahan, hubungan putusan terhadap tata kelola pemerintahan serta mengembangkan model fungsi pengawasan. Keterbaruan adalah model pengawasan oleh PTUN setelah disahkannya UU No. 30 Tahun 2014 tentang Administrasi Pemerintahan terhadap tindakan hukum Pemerintah. Metode yang digunakan adalah yuridis empiris, wawancara Hakim serta pengujian berdasar peraturan perundangan dan asas hukum.

Kata Kunci: Pengadilan Tata Usaha Negara, administrasi pemerintahan, tata kelola pemerintahan.

\section{Pokok Muatan}

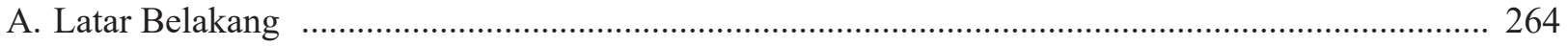

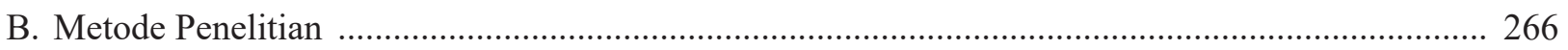

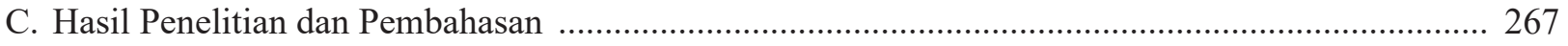

1. Pelaksanaan Fungsi Peradilan dan Fungsi Pengawasan oleh Pengadilan Tata Usaha Negara Sebelum dan Setelah Undang-Undang Nomor 30 Tahun 2014 tentang Administrasi

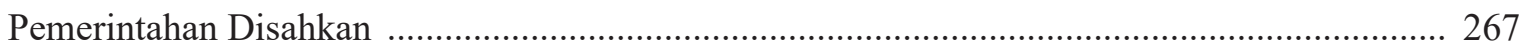

2. Kualitas Tata Kelola oleh Badan/Pejabat Tata Usaha Negara Setelah UU No. 30 Tahun 2014 tentang Administrasi Pemerintahan Disahkan ............................................................................ 272

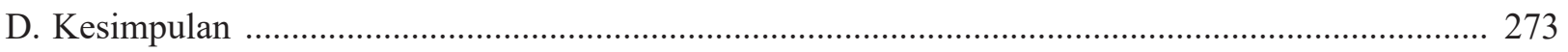

Penelitian (RPP) dibiayai oleh sumber dana PNBP DIPA Universitas Diponegoro Tahun 2016.

Alamat korespondensi: aputriyanti@yahoo.com.

*** Alamat korespondensi: leo_tukan@yahoo.com.au.

***** Alamat korespondensi:kartikawidyautama.undip@gmail.com. 


\section{A. Latar Belakang}

Perkembangan pemerintahan yang diikuti dengan semakin kompleksnya urusan pemerintahan, memerlukan pengaturan yang jelas dan tegas. Dibidang administrasi pemerintahan, peraturan perundangan yang diperlukan sebagai landasan hukum serta operasional penyelenggaraan pelbagai tugas dan fungsi pemerintahan, diatur dalam UU No. 30 Tahun 2014 tentang Administrasi Pemerintahan (selanjutnya disingkat UU AP).

UU AP sebagai hukum materiil terhadap Peradilan Tata Usaha Negara (selanjutnya disingkat PTUN), dan sebagai undang-undang yang pertama kali mengatur hal-hal terkait tindakan hukum pemerintah, mulai dari wewenang, syarat pembuatan keputusan, jenis keputusan, diskresi serta sanksi yang diberikan. UU AP dan UU Nomor 5 Tahun 1986 tentang Peradilan Tata Usaha Negara serta perubahannya, memiliki kedudukan hukum yang sama sebagai hukum positif serta saling memperkuat posisi satu terhadap yang lain dalam upaya penegakan hukum administrasi.

Sebelum diundangkannya UU AP, praktik penyelenggaraan pemerintahan lebih didasarkan pada doktrin hukum administrasi negara, teori dan praktik yang sudah sering dilakukan. Hal ini perlu dibenahi karena tidak menguntungkan bagi Pemerintah maupun warga masyarakat. Secara yuridis perlu dilakukan pembenahan karena segala tindakan hukum Pemerintah harus berdasar hukum sesuai dengan asas legalitas yang menjadi dasar penyelenggaraan pemerintahan.

Sebagai hukum materiil terhadap Peradilan Tata Usaha Negara, Undang-undang AP adalah landasan hukum untuk menguji keputusan tata usaha negara yang merupakan obyek sengketa serta perluasan obyek sengketa yang dapat diadili PTUN dan perluasan kewenangan PTUN. Penelitian tentang pengawasan oleh PTUN untuk mendorong terwujudnya pemerintahan yang bersih dan berwibawa yang dilakukan oleh W. Riawan Tjandra, menyebutkan bahwa: ${ }^{1}$

a. Pengawasan terhadap pemerintah pasca kemerdekaan menghadapi kendala belum adanya PTUN dan belum ada parameter yang jelas menyangkut kriteria perbuatan penguasa yang dikelompokkan kebijaksanaan atau perbuatan melawan hukum.

b. dalam kurun waktu 1986-2003, menghadapi kendala yang menyangkut dasar gugatan dan pelaksanaan putusan PTUN yang telah memperoleh kekuatan hukum tetap.

Berdasarkan hasil penelitian di atas, bahwa fungsi PTUN dalam mendorong terwujudnya Pemerintahan yang bersih dan berwibawa telah dilaksanakan, meskipun masih harus dioptimalkan capaian hasil yang diinginkan. Hal tersebut perlu ditindaklanjuti dengan langkah strategis dalam lingkungan intern Pemerintah. ${ }^{2}$ Hasil penelitian tersebut dilakukan sebelum disahkannya UU AP.

Perubahan di bidang perundang-undangan adalah alasan penting bagi peneliti untuk meneliti sekaligus menganalisis pelbagai perubahan yang timbul. Keterkaitan antara Pemerintah dalam menyelenggarakan pemerintahan perlu untuk diawasi dalam hal ini pengawasan dilakukan oleh PTUN. Menurut Muchsan pengawasan terhadap perbuatan pemerintah oleh kekuasaan kehakiman selalu dalam bentuk pengawasan represif artinya pengawasan dilakukan setelah ada perbuatan konkret dari pemerintah yang dianggap merugikan pihak lawan. ${ }^{3}$

Pendapat lain tentang peradilan di masa yang akan datang (future court) dengan tata kelola (good governance), perlu adanya perubahan mengenai dimensi peradilan, dikemukakan oleh Bruce Tonn sebagai berikut: ${ }^{4}$

\footnotetext{
W. Riawan Tjandra, 2009, Peradilan Tata Usaha Negara Mendorong Terwujudnya Pemerintahan yang Bersih dan Berwibawa, Universitas Atma Jaya Yogyakarta, Yogyakarta, hlm. 291-323.

Ibid., hlm. 324.

Muchsan, 2007, Sistem Pengawasan Terhadap Perbuatan Aparat Pemerintah Dan Peradilan Tata Usaha Negara, Liberty, Yogyakarta, hlm. 49.

Bruce Tonn, et al., "Futures of the Court: Fixed, flexible and Improvisational frameworks", Futures Journal, Vol. 44, Issues 9, November 2012, hlm. 2 .
} 
For this special issue on the future of governance, we considered the future of the courts based on the important role that they play in society and in governance, as suggested by the five dimensions and associated missions in the official plan of the Hawaii judiciary:

Dimension I: the judiciary as a branch of Government.

Mission 1: to uphold the Constitution - the government it creates, the rights and liberties it guarantees, and the policies and principles which it embodies

Dimension II: the judiciary as a Dispute Resolution Forum.

Mission 2: to ensure to the people of the State the highest standard of justice attainable under our system of government by assuring an equitable and expeditious resolution of all cases and controversies properly brought to the state courts.

Dimension III : the judiciary as a Public Agency.

Mission 3: to provide for, promote and ensure the effective, economical, and efficient utilization of public resources in the administration of judicial system.

Dimension IV: the judiciary as a Subsystem of Legal System.

Mission 4: to promote the effective and expeditious administration of justice by and among the various subsystems of the legal system.

Dimension V: the judiciary as an Institution of Changing Society.

Mission 5: to anticipate and respond to the changing judicial needs of society.

Prinsip-prinsip tata kelola pemerintahan yang baik antara lain dikemukakan oleh British and Irish Ombudsman Association yang terdiri atas 6 (enam) prinsip yaitu: ${ }^{5}$

a. Independence: ensuring and demonstrating the freedom of the office holder from interference in decision making.

b. Effectiveness: ensuring that the scheme delivers quality outcome efficiently and represent food value for money. c. Openess and Transparency: ensuring openess and trancparency in order that stakeholders can have confidence in the decision-making and management process of the scheme.

d. Accountability: ensuring that all members of the scheme, including the office holder, staff members and members of any governing body, are seen to be responsible and accountable for their decisions and actions, including the stewardship of fund (with due regard to the independence of the office holder).

e. Integrity: ensuring straightforward dealing and completness, based on honestly, selflessness and objectivity, and ensuring high standards of probity and propierty in the conduct of the scheme's affairs and complaint decision making.

f. Clarity of purpose: ensuring that stakeholders know why the scheme exists and what it does, and what to expect from it.

Ada beberapa kriteria kunci yang dikemukakan dalam laman $O E C D$ programme on Public Management and Governance, mengenai konsensus umum (general consensus) untuk mendefinisikan sebagai good governance atau tata kelola pemerintahan yang baik, yang sedikit berbeda dari yang tercantum di atas, yaitu: ${ }^{6}$
a. Technical and managerial competence;
b. Organisational capacity;
c. Reliability, predictability and the rule of law;
d. Accountability;
e. Transparency and open information systems;
f. Participation.

Salah satu hal utama dalam tata kelola pemerintahan adalah sektor pelayanan publik, yang langsung berhubungan dengan masyarakat. Menurut Ruth Hubbard dalam "Criteria of Good Governance" menyebutkan bahwa tata kelola

\footnotetext{
British dan Irish Ombudsman Associaton, "Guide to Principles of Good Governance", www.ombudsmanassociation.org/docs/ BIOAGovernanceGuideOct09.pdf, diakses pada Tanggal 20 Maret 2016.

OECD programme on Public Management and Governance (PUMA), "Promoting Good Governance", http://www.gdrc.org/u-gov/docoecd_ggov.html, diakses 20 Maret 2016.
} 
pemerintahan yang baik terdiri dari 3 (tiga) pilar utama, yaitu sektor privat, sektor publik dan masyarakat. Tiga hal ini bersinergi secara terpadu dengan pemerintah untuk membangun "equilibrium among them", dan menurut Hubbard, ketiga hal tersebut sebagai dasar pembangunan demokrasi yang berkelanjutan. ${ }^{7}$

S.F.Marbun menyebutkan bahwa good governance terkait dengan clean government karena secara filosofis suatu pemerintahan yang baik akan melahirkan pemerintah yang bersih atau sebaliknya yaitu pemerintah yang bersih merupakan syarat bagi proses atau terselenggaranya pemerintahan yang baik. Dalam kenyataannya, pemerintahan yang baik belum tentu merupakan pemerintahan yang bersih. Good governance mencakup berbagai aspek yaitu politik, sosial, ekonomi dan aspek kehidupan bernegara lainnya. Sehingga good governance dipahami sebagai proses pelaksanaan atau penyelenggaraan kekuasaan yang meliputi aspek politik dan pengaturan sumber daya pembangunan. ${ }^{8}$

H.A. Muin Fahmal mengemukakan good governance berorientasi pada 2 (dua) aspek, yaitu pertama orientasi ideal yang diarahkan pada pencapaian tujuan nasional, kedua, pemerintahan yang berfungsi secara ideal, efektif dan efisien untuk mencapai tujuan nasional, yang keseluruhan menitikberatkan perlu adanya akuntabilitas, kompetensi, struktur serta mekanisme politik dan administrasi berfungsi secara efisien dan efektif. ${ }^{9}$

Bentuk pengawasan yang dilakukan oleh PTUN mengalami perubahan terkait dengan substansi UU AP. Ada 3 hal penting terkait pengawasan yaitu unsur penyalahgunaan wewenang, keputusan fiktif positif serta perluasan obyek sengketa. Dalam hal pejabat tata usaha negara melakukan penyalahgunaan wewenang, bagaimana pengawasan yang dilakukan oleh PTUN? Apakah pengawasan terhadap penyalahgunaan wewenang sudah memadai dengan perundangan yang sudah ada atau perlu perundangan baru? Terkait keputusan fiktif positif, pengawasan oleh Pengadilan, belum di atur secara jelas. Demikian pula apabila ada perluasan obyek sengketa untuk diperiksa oleh PTUN, perlu dikaji model pengawasan yang benar, agar pemerintahan dapat dilaksanakan dengan baik dan terwujud tata kelola pemerintahan yang baik. Permasalahan yang akan diteliti yaitu: (1) Bagaimana pelaksanaan fungsi peradilan dan fungsi pengawasan oleh PTUN sebelum dan setelah UU AP disahkan?; (2) Bagaimana kualitas tata kelola Badan/Pejabat Tata Usaha Negara setelah UU AP disahkan?

\section{B. Metode Penelitian}

Penelitian ini menggunakan metode doktrinal dan non-doktrinal atau empiris. Penggabungan metode ini untuk melihat jumlah sengketa tata usaha yang masuk ke PTUN periode sebelum dan setelah disahkannya UUAPyang diperoleh berdasarkan data di PTUN, serta di analisa sesuai dengan peraturan perundangan /normatif yang berlaku. Untuk lebih memperjelas analisa, penelitian juga didukung wawancara langsung dengan Hakim PTUN sebagai pihak yang terlibat langsung dalam memeriksa, memutus dan menyelesaikan sengketa tata usaha negara. Penelitian dilakukan di PTUN Semarang, PTUN Yogyakarta, PTUN Surabaya, PTUN Jakarta dan PTUN Bandung, guna mengetahui sengketa tata usaha negara yang masuk untuk diperiksa.

Sumber data sekunder yang digunakan meliputi bahan hukum primer dan bahan hukum sekunder. Bahan hukum primer terdiri dari peraturan perundang-undangan dan putusan Hakim yang telah memperoleh kekuatan hukum tetap. Putusan Pengadilan adalah bahan hukum primer yang memiliki otoritas, karena merupakan konkretisasi dari perundang-undangan. Putusan Pengadilan inilah sebenarnya yang merupakan law in action. Bahan hukum sekunder berupa semua publikasi

Ruth Hubbard. "Criteria of Good Governance", Optimum The Journal of Public Management, Vol. 30, No. 2.

S.F. Marbun, 2014, Asas-asas Umum Pemerintahan Yang Layak, FH UII Press Yogyakarta, Yogyakarta, hlm. 84-86.

H.A.Muin Fahmal, 2006, Peran Asas-asas Umum Pemerintahan Yang Layak Dalam Mewujudkan Pemerintahan yang Bersih, UII Pres, Yogyakarta, hlm. 174. 
tentang hukum yang bukan merupakan dokumen resmi.

Proses analisa data dimulai dengan melakukan inventarisasi seluruh peraturan perundangan yang merupakan bahan hukum primer, untuk selanjutnya dikelompokkan sesuai dengan jenis yang diperlukan. Langkah pengelompokan data yang berupa putusan pengadilan untuk lebih memudahkan proses analisa data.

Reduksi data dilakukan apabila ada bahan hukum primer yang tidak sesuai dengan batasan data yang ditentukan. Analisa data dilakukan secara sistematis sesuai dengan teori yang digunakan untuk disusun sebagai kesimpulan yang menjawab permasalahan.

\section{Hasil Penelitian dan Pembahasan}

1. Pelaksanaan Fungsi Peradilan dan Fungsi Pengawasan oleh Pengadilan Tata Usaha Negara Sebelum dan Setelah UndangUndang Nomor 30 Tahun 2014 tentang Administrasi Pemerintahan Disahkan

Tujuan dan fungsi pengadilan tata usaha negara saling terkait hal ini sesuai dengan isi Pasal 47 UU No. 5 Tahun 1986 serta tujuan pembentukannya yaitu memberi perlindungan hukum kepada rakyat pencari keadilan, yang dirugikan akibat dikeluarkannya suatu Keputusan Tata Usaha Negara. Fungsi pengadilan sebagai badan atau lembaga dan peradilan sebagai proses memiliki keterkaitan, hal ini dipertegas oleh Bagir Manan yang menyebutkan hal tersebut dapat ditinjau dari beberapa segi: ${ }^{10}$

1. Dari segi tujuan bernegara, yang menyebutkan antara lain memajukan kesejahteraan umum bagi kemakmuran dan keadilan sosial seluruh rakyat Indonesia. Tujuan ini melekat pada pengadilan dan peradilan sebagai institusi yang menjalankan fungsi negara.
2. Segi mewujudkan tujuan-tujuan hukum, yaitu keadilan, ketertiban, kepuasan pencari keadilan dan lainlain. Fungsi ini adalah fungsi tradisional pengadilan dan peradilan serta sangat sulit untuk diwujudkan. Tujuan hukum tidak selalu berjalan beriringan seimbang, ada beberapa hal yang saling bertentangan satu dengan yang lain. Perlu adanya keseimbangan untuk dapat menjaga agar hal-hal tersebut dapat terlaksana atau tercapai.

3. Segi menegakkan hukum. Esensi menegakkan hukum adalah menjalankan dan mempertahankan hukum, dalam hal ini pengadilan wajib memutus berdasar hukum.

Pengadilan Tata Usaha Negara menyelenggarakan fungsi peradilan terutama terkait dengan pentingnya asas legalitas yang menjadi dasar pengujian obyek sengketa. Pengujian terhadap obyek sengketa sepenuhnya didasarkan pada dasar hukum kewenangan yang dimiliki oleh Pejabat Tata Usaha Negara atau Badan Tata Usaha Negara, serta prosedur penerapan hukum dikeluarkannya keputusan tata usaha negara. Dalam negara hukum, asas legalitas menjadi dasar penyelenggaraan pemerintahan yang memberikan kewenangan penyelenggaraan negara.

Fungsi peradilan yang dilaksanakan oleh PTUN sebelum UU AP berlaku sesuai dengan isi Pasal 24 UUD 1945 setelah amandemen. Di satu sisi, fungsi PT UN tidak hanya sebagaimana dicantumkan dalam Pasal 47 UU No. 5 Tahun 1986, tetapi tercakup pula tujuan yang ingin dicapai adalah keadilan dan menegakkan hukum serta melindungi hak warga negara. Fungsi pengawasan yang dilakukan oleh PTUN memiliki ciri atau unsur yang berbeda, meskipun demikian sebenarnya juga harus dilihat secara keseluruhan dalam konteks pengawasan penyelenggaraan pemerintahan agar

10 Bagir Manan, 2009, Persepsi Masyarakat Mengenai Pengadilan dan Peradilan Yang Baik dalam Menegakkan Hukum Suatu Pencarian, Asosiasi Advokat Indonesia, Jakarta, hlm. 223-225. 
tercipta pemerintahan yang baik. Pengawasan oleh PTUN dilakukan dengan menguji legalitas meliputi kewenangan, prosedur dan substansi keputusan tata usaha negara, penerapan hukum serta pelaksanaan putusan yang memperoleh kekuatan hukum tetap. Proses pengawasan oleh lembaga peradilan agar dapat menjaga keserasian, keseimbangan kepentingan antara warga negara, negara, individu.

Berdasarkan penelitian yang dilakukan, fungsi pengawasan mulai dilakukan sejak ada gugatan yang di daftarkan ke Pengadilan Tata Usaha Negara. Dalam praktik fungsi pengawasan berjalan bersama-sama dengan fungsi peradilan. Hal ini dapat dilihat dari penjelasan berikut: Pengadilan akan memulai untuk memeriksa gugatan yaitu pembatalan keputusan tata usaha negara. Berarti, fungsi pengawasan juga sudah berjalan yaitu dengan memeriksa syarat formil dan materiil gugatan. Majelis Hakim akan memeriksa penerapan hukum serta pengujian dalam proses penerbitan Keputusan Tata Usaha Negara, hal ini juga sebagai fungsi pengawasan.

Sebelum UU AP disahkan, fungsi peradilan dan pengawasan dilakukan oleh PTUN secara bersama-sama, serta melakukan pengujian terhadap penerapan hukum, bersifat ex-tunc yang berarti pengujian terhadap fakta-fakta dan keadaan pada saat dikeluarkan surat keputusan yang disengketakan. ${ }^{11}$ Setelah UU AP berlaku, memperkuat fungsi pengawasan yang dilakukan oleh PTUN. Selain itu memperluas fungsi peradilan karena adanya perluasan kewenangan mengadili yaitu Pasal 21, Pasal 53, Pasal 87. Pasal 21 menyebutkan "Pengadilan berwenang menerima, memeriksa dan memutus ada atau tidak adanya unsur penyalahgunaan wewenang oleh Pejabat Pemerintahan, dan harus diputus dalam waktu 21 hari kerja sejak permohonan diajukan." 2 Pada pasal tersebut juga disebutkan bahwa permohonan dapat diajukan banding ke Pengadilan Tinggi Tata Usaha Negara dan wajib memutus permohonan banding dalam waktu 21 hari kerja sejak permohonan diajukan dan keputusan bersifat final mengikat. ${ }^{13}$ Pasal 53 menyebutkan Pengadilan wajib memutus permohonan yang diajukan Pemohon untuk memperoleh putusan penerimaan, dalam jangka waktu 21 hari kerja. ${ }^{14}$ Badan dan atau Pejabat Pemerintah wajib menetapkan Keputusan untuk melaksanakan putusan Pengadilan paling lama 5 hari kerja sejak putusan ditetapkan. ${ }^{15}$ Pasal 87 menyebutkan bahwa Keputusan Tata Usaha Negara sebagaimana dimaksud dalam peraturan perundangan tentang Pengadilan Tata Usaha Negara, harus dimaknai sebagai: ${ }^{16}$ (a) penetapan tertulis yang juga mencakup tindakan faktual, (b) Keputusan Badan dan/atau Pejabat Pemerintah dilingkungan eksekutif, legislatif, yudikatif dan penyelenggara negara lainnya, (c) berdasarkan ketentuan perundangan dan AUPB, (d) bersifat final dalam arti lebih luas, (e) Keputusan yang berpotensi menimbulkan akibat hukum, (f) Keputusan yang berlaku bagi warga masyarakat.

Sistem Informasi Penelusuran Perkara (SIPP) di setiap Pengadilan, pembagian dikelompokkan menjadi tiga, yaitu gugatan, permohonan UU AP, gugatan keberatan(KIP). Untuk permohonan UUAP, dibedakan dengan pencantuman FP (Fiktif Positif) berdasarkan Pasal 53 UU AP di setiap permohonan yang masuk. Termasuk gugatan, meliputi gugatan di bidang kepegawaian, pertanahan, perijinan, lelang dan lain-lain.

2 Pasal 21 ayat (1) Undang-Undang Nomor 30 Tahun 2014 tentang Administrasi Pemerintahan (Lembaran Negara Republik Indonesia Tahun 2014 Nomor 292, Tambahan Lembaran Negara Republik Indonesia Nomor 5601).

13 Pasal 21 ayat (3) Undang-Undang Nomor 30 Tahun 2014 tentang Administrasi Pemerintahan (Lembaran Negara Republik Indonesia Tahun 2014 Nomor 292, Tambahan Lembaran Negara Republik Indonesia Nomor 5601).

14 Pasal 53 ayat (4) Undang-Undang Nomor 30 Tahun 2014 tentang Administrasi Pemerintahan (Lembaran Negara Republik Indonesia Tahun 2014 Nomor 292, Tambahan Lembaran Negara Republik Indonesia Nomor 5601).

15 Pasal 53 ayat (5) Undang-Undang Nomor 30 Tahun 2014 tentang Administrasi Pemerintahan (Lembaran Negara Republik Indonesia Tahun 2014 Nomor 292, Tambahan Lembaran Negara Republik Indonesia Nomor 5601).

16 Pasal 87 Undang-Undang Nomor 30 Tahun 2014 tentang Administrasi Pemerintahan (Lembaran Negara Republik Indonesia Tahun 2014 Nomor 292, Tambahan Lembaran Negara Republik Indonesia Nomor 5601). 
Tabel 1.

Data gugatan, permohonan UU AP, Keberatan KIP

\begin{tabular}{llclllll}
\hline \multirow{2}{*}{ PTUN } & \multicolumn{3}{c}{ Tahun 2015 } & \multicolumn{3}{c}{ Tahun 2016 } \\
\cline { 2 - 8 } & Gugatan & $\begin{array}{c}\text { Permohonan } \\
\text { UU AP }\end{array}$ & $\begin{array}{c}\text { Keberatan } \\
\text { KIP }\end{array}$ & Gugatan & $\begin{array}{c}\text { Permohonan } \\
\text { UU AP }\end{array}$ & $\begin{array}{c}\text { Keberatan } \\
\text { KIP }\end{array}$ \\
\hline Semarang & 32 & - & - & 31 & 3 & - \\
\hline Yogyakarta & 6 & - & - & 6 & - & - \\
\hline Surabaya & 45 & - & - & 97 & - & - \\
\hline Jakarta & 89 & 3 & 1 & 137 & 1 & 4 \\
\hline Bandung & 57 & - & - & 28 & - & - \\
\hline
\end{tabular}

Sumber: Data primer, Tahun $2015-2016 .{ }^{17}$

Berdasarkan data yang ada, jumlah gugatan yang masuk ke PTUN tahun 2015 - 2016 lebih banyak dibandingkan permohonan berdasar pasal 53 UU AP dan keberatan Keterbukaan Informasi Publik (KIP). Fungsi peradilan yang sudah ada tetap berjalan, namun dengan catatan khusus yaitu ada perluasan fungsi peradilan yaitu tidak saja memutus sengketa, tetapi juga memeriksa permohonan dan keberatan.

Setelah UU AP disahkan, penambahan kewenangan PTUN juga diikuti dengan fungsi pengawasan menjadi lebih intensif. ${ }^{18}$ Terkait dengan isi Pasal 87 UU AP adanya perbedaan pendapat atau pandangan mengenai keputusan tata usaha negara dan batasannya menimbulkan permasalahan dalam praktik. Hakim memiliki pandangan yang berbedabeda dalam menafsirkan isi Pasal 87, sementara di satu sisi adagium menyebutkan bahwa hukum tidak boleh ditafsirkan. Perbedaan pandangan ini timbul karena belum ada penjelasan yang lebih jelas mengenai, misal apakah yang dimaksud dan apa batasan tindakan faktual yang dilakukan oleh Pemerintah. ${ }^{19}$ Substansi Pasal 87 dapat memberi berbagai penafsiran dalam praktik, untuk lebih menjamin kepastian hukum, perlu ada peraturan pemerintah yang memberi batasan dan penjelasan secara benar. Hal tersebut sebagai salah satu faktor belum ada gugatan masuk yang berdasar Pasal 87 .

Substansi Pasal 21 UU AP karena ada perubahan politik hukum Pemerintah. Penyalahgunaan wewenang sesungguhnya adalah ranah hukum administrasi negara, dengan landasan berpikir secara hukum, bahwa wewenang yang dimiliki oleh Pejabat Tata Usaha Negara berdasarkan peraturan perundangan yang berlaku serta untuk pelaksanaan pemerintahan. Pemerintah berusaha untuk meletakkan secara benar, bahwa wewenang sepenuhnya berada pada ranah hukum administrasi negara. ${ }^{20}$ Masih ada pula ketidakjelasan tentang kerugian yang timbul dari adanya penyalahgunaan wewenang, UU AP menganut "actual loss" atau kerugian senyata-nyatanya, sementara UU No. 31 Tahun 1999 tentang Pemberantasan Tindak Pidana Korupsi jo UU 20 Tahun 2001 tentang Perubahan Atas UU No. 31 Tahun 1999 tentang Pemberantasan Tindak Pidana Korupsi menganut "potential loss". ${ }^{21}$ Mengenai kewenangan PTUN dalam memeriksa ada atau tidaknya unsur penyalahgunaan wewenang, menurut Andhi Nirwanto, adalah domain PTUN dengan penjelasan bahwa wewenang oleh pejabat Pemerintah harus dimaknai sebagai perbuatan hukum dalam konteks tata usaha negara. ${ }^{22}$

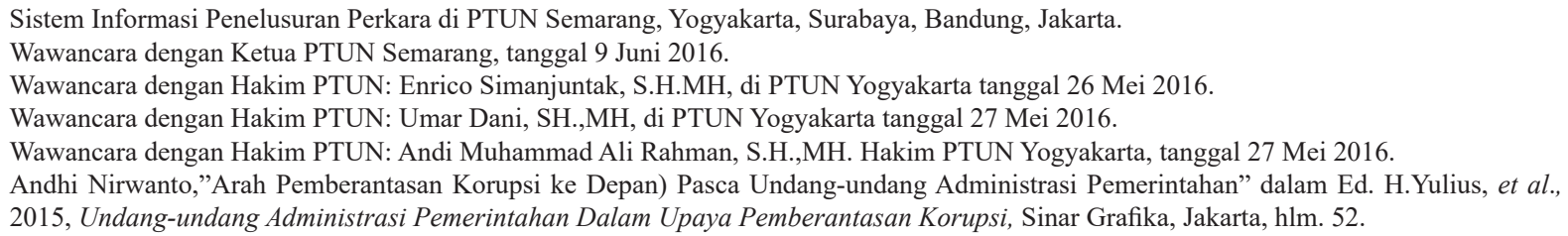


Pasal 53 adalah salah satu pasal yang memperluas kewenangan PTUN dalam fungsi peradilan, karena dapat diajukan permohonan ke PTUN agar memerintahkan Badan Tata Usaha Negara mengeluarkan keputusan berdasarkan permohonan yang diajukan. Untuk dapat memenuhi ketentuan isi Pasal 53, ada beberapa hal yang harus dilengkapi agar Pengadilan dapat menerbitkan penetapan terkait permohonan, yaitu: ${ }^{23}$

1. Apakah ada atau tidak kewajiban hukum yang harus dipenuhi oleh Pejabat atau Badan Tata Usaha Negara?

2. Apakah permohonan yang diajukan sudah lengkap sesuai dengan ketentuan perundang-undangan yang berlaku?

3. Apakah ada sikap diam dari Pemerintah (Pejabat atau Badan Tata Usaha Negara)?

Terkait dengan Pasal 53, adanya pengajuan permohonan oleh Pemohon kepada Pengadilan, maka keluarannya yang benar adalah penetapan, bukan putusan. Hal ini didasarkan pada pemikiran bahwa adanya putusan Pengadilan karena ada sengketa yang masuk dan diperiksa, diputus oleh Pengadilan. Sementara, permohonan diajukan oleh Pemohon kepada Pengadilan, sehingga keluarannya adalah penetapan, karena bukan sengketa. ${ }^{24}$ Perlu di kaji kembali dalam substansi Pasal 53, apakah putusan atau penetapan yang dikeluarkan oleh Pengadilan, terkait dengan permohonan yang diajukan Pemohon.

Isi Pasal 53 UU AP menunjukkan adanya pergeseran lembaga peradilan dalam hal ini PTUN dari semula duduk pada kursi yudikatif, menjadi duduk pada kursi eksekutif secara tidak langsung. Dijelaskan lebih lanjut sebagai berikut: putusan yang dikeluarkan oleh Pengadilan dan berisi perintah kepada Badan atau Pejabat Tata Usaha Negara bersangkutan, dipakai sebagai dasar atau landasan bagi pemohon untuk memperoleh haknya.
Jadi tanpa mengindahkan ada atau tidak ada keputusan tata usaha negara yang dikeluarkan oleh Badan atau Pejabat Tata Usaha Negara, pemohon menggunakan putusan pengadilan sebagai dasar untuk memperoleh hak sesuai permohonan yang diajukan ke Badan atau Pejabat Tata Usaha Negara. Hal ini terjadi karena tidak ada sanksi administratif atau pengaturan yang jelas dalam perundangundangan, apabila Badan atau Pejabat Tata Usaha Negara tidak melaksanakan putusan Pengadilan dalam waktu 5 (lima) hari sejak putusan ditetapkan..$^{25}$ Keadaan tersebut menunjukkan ada pergeseran fungsi peradilan dalam dimensi "as a dispute resolution forum" yaitu peradilan sebagai forum penyelesaian sengketa tidak sekedar mengadili perkara, "as an isntitution of changing society" sebagai institusi yang melakukan perubahan pola kehidupan masyarakat artinya agar masyarakat memahami hak warga negara

Untuk mengetahui jenis permohonan berdasar Pasal 21, 53 dan gugatan Pasal 87 yang masuk ke PTUN, dapat dilihat pada Tabel 2.

Tabel 2 menunjukkan jumlah permohonan berdasar Pasal 21, 53 dan gugatan berdasar Pasal 87 mulai ada tahun 2015, karena UU AP disahkan tanggal 17 Oktober 2014. Pengajuan permohonan berdasar Pasal 53 meskipun jumlahnya sedikit, tetapi tetap ada pengajuan permohonan, dibandingkan dengan permohonan Pasal 21 dan gugatan berdasar Pasal 87.

Dari Tabel 2 diketahui bahwa permohonan Pasal 53 menunjukkan pergeseran fungsi peradilan, karena bentuk pengajuan permohonan, bukan penyelesaian sengketa. Dalam hal ini, permohonan Pasal 53 dilihat sebagai dimensi penyelesaian sengketa atau " as a disputeresolution forum". Fungsi pengawasan oleh PTUN terhadap penyelenggaraan pemerintahan mengalami perkembangan, karena pengaruh praktik penyelenggaraan negara serta perkembangan teknologi informasi. Bentuk

\footnotetext{
Wawancara dengan Hakim PTUN Jakarta Tri Cahya Indra Permana,S.H.M.H, tanggal 18 Juli 2016.

Wawancara dengan Ketua PTUN Surabaya, tanggal 25 Juli 2016.

Wawancara dengan Hakim PTUN Jakarta, Teguh Satya Bhakti, S.H.,MH, tanggal 19 Juli 2016
} 
pengawasan yang selama ini melekat dengan sehingga peran PTUN semakin efektif dalam fungsi peradilan, harus dikembangkan dan diubah, penegakan hukum.

Tabel 2.

Permohonan berdasar Pasal 21, 53 dan gugatan Pasal 87 UU No.30 Tahun 2014 tentang Administrasi Pemerintahan

\begin{tabular}{lcccccc}
\hline \multirow{2}{*}{ PTUN } & \multicolumn{3}{c}{ Tahun 2015 } & \multicolumn{3}{c}{ Tahun 2016 } \\
\cline { 2 - 7 } & $\begin{array}{c}\text { Permohonan } \\
\text { Pasal 21 }\end{array}$ & $\begin{array}{c}\text { Permohonan } \\
\text { Pasal 53 }\end{array}$ & Gugatan Ps & Permohonan & Permohonan & Gugatan \\
& - & - & 87 & Ps 21 & Ps 53 & Ps1 87 \\
\hline Semarang & - & - & - & - & 3 & - \\
\hline Yogyakarta & - & - & - & - & - & - \\
\hline Surabaya & - & 3 & - & - & 1 & - \\
\hline Jakarta & - & - & - & - & - & - \\
\hline Bandung & & & - & & & - \\
\hline
\end{tabular}

Sumber: Data primer, tahun $2015-2016^{26}$

Menurut Irfan Fachruddin, diberikan pernyataan sebagai berikut:

Sebelum pengawasan represif dimulai, hakim sebaiknya menggunakan bentuk pengawasan refleksif yang dapat dipadankan dengan prosedur damai dalam hukum acara perdata. Bentuk pengawasan refleksif didasarkan pada dasar permusyawaratan, saling menghormati dan mempercayai, antara pengawas dan yang diawasi siap untuk saling berunding, tidak ada penekanan dan pelaksanaannya diserahkan kepada pihak yang diawasi. Pengawasan badan peradilan termasuk pengawasan represif. ${ }^{27}$

Sehubungan dengan fungsi pengawasan oleh Pengadilan, pendapat di atas dapat dilihat merupakan pergeseran fungsi peradilan ke arah future judiciary, yaitu "as a dispute resolution forum" yang menyelesaikan sengketa melalui forum penyelesaian sengketa, tidak melalui peradilan. Konsep untuk mengembangkan model fungsi pengawasan oleh PTUN, juga dapat menggunakan kajian perbandingan di Belanda yang menggunakan "New Approach of the Adminisitrative Law Justice". Diuraikan oleh Andre Verburg dan Ben Schueler dalam artikel ilmiah yang berjudul "Procedural Justice in Dutch Administrative Court Proceedings" sebagai berikut: ${ }^{28}$

[...] in this approach, the judge tries to implement strategies and actions which are presumed by the administrative courts to help parties to perceive the way they are treated within proceedings as fair and just [...] $A$ spesific trait of the New Approach is that the judge not only offers procedural information to parties (how these proceedings will continue, what steps will be taken to reach a decision), but also offers material information (what possible outcomes are to be expected when I come to a ruling, what additional evidence is needed from parties to convince the judge, and possibly the other party), transparency and preliminary judgement. Both quotations by Lind and Tyler reflect on this kind of material explanation, but the main procedural justice research focuses on procedural information.

Dari yang dikemukakan di atas, Hakim memiliki peran penting yaitu yang disebut New Approach suatu pendekatan baru bahwa Hakim tidak saja menawarkan informasi yang sifatnya

\footnotetext{
Sistem Informasi Penelusuran Perkara di PTUN Semarang, Yogyakarta, Surabaya, Jakarta dan Bandung.

Irfan Fachruddin, 2004, Pengawasan Peradilan Administrasi Terhadap Tindakan Pemerintah, Alumni, Bandung, hlm. 375.

Andre Verburg dan Ben Schueler, "Procedural Justice in Dutch Administrative Court Proceedings", Utrecht Law Review. Vol. 10. Issue 4 November 2014, hlm. 66.
} 
prosedural tetapi juga menawarkan informasi yang sifatnya substansial, transparansi. Membangun model pengawasan oleh PTUN yang dihubungkan dengan kajian perbandingan di atas, memerlukan mind-set atau cara pandang /cara berpikir sedikit berbeda dengan peradilan yang sudah ada dan bersifat konvensional. Hal ini harus didukung oleh peraturan perundangan yang mengatur sistem peradilan tata usaha negara dan peraturan terkait lainnya. Hakim sebagai bagian dari Sistem Peradilan Tata Usaha Negara berperan aktif dalam menggali AUPB dan menjadikan sebagai dasar pertimbangan hukum Hakim, yang melalui putusan memiliki andil penting untuk mengembangkan fungsi pengawasan yang lebih baik.

Data yang ditampilkan pada Tabel 1 menunjukkan jumlah gugatan yang masuk lebih banyak dibandingkan permohonan berdasar Pasal 21, 53 dan gugatan Pasal 87 UUAP. Tabel 2 menunjukkan bahwa jumlah permohonan berdasar Pasal 53 lebih banyak dibandingkan permohonan berdasar Pasal 21 dan gugatan Pasal 87. Perluasan fungsi peradilan ditunjukkan secara nyata pada adanya permohonan Pasal 53, namun demikian, gugatan pembatalan keputusan tata usaha negara tetap banyak diajukan.

Pelaksanaan fungsi peradilan dan fungsi pengawasan yang dilaksanakan oleh PTUN setelah UU AP disahkan, mengalami perluasan-perluasan fungsi peradilan yaitu selain memeriksa, memutus dan menyelesaikan sengketa tata usaha negara. juga memutus permohonan yang diajukan Pemohon dengan dasar hukum yang berbeda. Fungsi pengawasan oleh Pengadilan Tata Usaha Negara mengalami perluasan sesuai dengan perluasan fungsi peradilan dan makna keputusan tata usaha negara berdasar Pasal 87 UU AP.

Sejalan dengan dinamika pemerintahan, sebagai kekuasaan yudikatif juga harus dapat menyesuaikan sehingga peran lembaga peradilan tidak saja untuk memeriksa, memutus dan menyelesaikan sengketa tetapi juga memiliki peran yang lain. Peran PTUN juga mengalami perluasan menyesuaikan UU AP sebagai hukum materiil, mulai ada peran sebagai "dispute resolution forum", "as an institution of changing society", " as public agency" yang melengkapi fungsi peradilan yang sudah ada selama ini, untuk menuju ke arah future court sebagaimana dikemukakan oleh Bruce Tonn et.al di atas. Perkembangan ke arah future court tetap harus berdasarkan Pancasila, UUD 1945 dan tujuan negara.

\section{Kualitas Tata Kelola oleh Badan/Pejabat Tata Usaha Negara Setelah UU No. 30 Tahun 2014 tentang Administrasi Pemerintahan Disahkan}

Konteks negara hukum, peran aktif pemerintah dapat menimbulkan kerugian warga negara, tetapi juga merupakan kewajiban pemerintah untuk melindungi hak warga negara. Paham negara hukum juga menghendaki pemerintahan yang baik dan bersih (good and clean government), bahkan menghendaki agar tidak terjadi apa yang disebut "misbruik " atau abus de droit atau detournement de pouvoir yang memang bertentangan dengan hakhak warga masyarakat dan prinsip negara hukum sejati. ${ }^{29}$

UU AP telah mengatur secara jelas mulai dari wewenang, standar operasional prosedur pembuatan keputusan, perubahan, pencabutan, penundaan, pembatalan suatu keputusan, yang harus digunakan secara benar oleh Pejabat Tata Usaha Negara, tetapi dari Tabel 1 di atas, gugatan pembatalan keputusan tetap banyak diajukan ke PTUN. Hal ini menunjukkan kualitas tata kelola pemerintahan masih perlu diperbaiki dan ditingkatkan.

Kualitas tata kelola pemerintahan dipengaruhi oleh alasan-alasan yang menjadi dasar gugatan karena kurangnya pemahaman secara mendalam tentang arti AUPB, kurangnya kemampuan manajerial dalam mengelaborasi AUPB serta kurang memahami standar operasional prosedur penyusunan keputusan tata usaha negara, merupakan salah satu faktor kualitas tata kelola belum berjalan dengan baik. Kurang cermatnya dalam menyusun, memper- 
siapkan keputusan dan/atau tindakan, penyediaan pelayanan yang belum optimal, kemanfaatan bagi penerima keputusan dan/ atau tindakan termasuk bagi warga masyarakat, perlunya netralitas pejabat pemerintah dan kurang mengutamakan kepentingan umum, kesejahteraan masyarakat adalah beberapa alasan yang menjadi dasar gugatan .

Salah satutolokukuruntukmelihatkualitastata kelola dapat digunakan kriteria yang dikemukakan oleh British and Irish Ombudsman Association, $O E C D$, antara lain integrity, accountability, effectiveness, technical and managerial competence, clarity of purpose, reliabiity, predictability and the rule of law, terkait dengan gugatan yang diajukan. Integritas terkait dengan sikap secara jujur, terbuka melaksanakan tugasnya, memiliki komitmen untuk memberi pelayanan publik yang terbaik. Akuntabilitas bahwa dalam melaksanakan setiap pekerjaan selalu diikuti rasa tanggung jawab dan memahami secara benar tugas kewajiban. Efektif dalam bekerja, serta kejelasan dari tujuan pekerjaan dan mempertimbangkan semua kemungkinan yang akan terjadi. Transparansi mulai dari proses penyusunan keputusan tata usaha negara, termasuk pula dipatuhi standar operasional prosedur untuk memberi kejelasan secara prosedural. Aspekaspek tersebut perlu dikelola secara benar dengan kemampuan manajerial yang baik, agar tercapai tata kelola pemerintahan yang baik.

Orientasi ideal yang hendak dicapai adalah dengan meningkatkan kemampuan manajerial dalam mengelola pelbagai aspek tata kelola pemerintahan untuk dapat mencapai tujuan nasional serta peningkatan kualitas tata kelola, mulai dengan membangun integritas, akuntabilitas, transparansi, efektif dan efisien secara bertahap dan berkelanjutan. Artinya terus dilakukan upaya untuk mencapai tata kelola pemerintahan yang baik, yang dimulai dengan membangun pola pikir mengutamakan pelayanan publik dengan baik dan benar.

Salah satu syarat materiil gugatan adalah bertentangan dengan Asas Umum Pemerintahan yang Baik (AUPB), dan termasuk AUPB sebagaimana dicantumkan dalam Pasal 10 UU No.
30 Tahun 2014 tentang Administrasi Pemerintahan dan UU No. 28 Tahun 1999 tentang Penyelenggaraan Pemerintahan yang bersih dan bebas dari Korupsi, Kolusi dan Nepotisme. AUPB selain sebagai syarat materiil pengajuan gugatan, juga sebagai dasar pengujian terhadap obyek sengketa dan dapat digunakan pula untuk mengetahui kualitas tata kelola pemerintahan. Secara umum AUPB yang sering digunakan adalah asas kecermatan yang mewajibkan bahwa suatu keputusan dan/ atau tindakan harus didasarkan pada informasi dan dokumen yang lengkap yang harus dipersiapkan secara cermat sebelum keputusan dan/atau tindakan ditetapkan dan/atau dilakukan. Asas pelayanan yang baik agar pelayanan diberikan sesuai dengan standar operasional prosedur yang telah ditetapkan, termasuk pula biaya yang diperlukan.

AUPB berperan penting dalam penyelenggaraan pemerintahan, dan terus berkembang sesuai keadaan, sehingga bersifat dinamis dan fleksibel, karena selalu menyesuaikan perkembangan. Kualitas tata kelola pemerintahan tetap harus bertitik tolak dari AUPB, baik yang dinormakan perundangan maupun yang dicantumkan sebagai dasar pertimbangan hukum Hakim dalam putusan Pengadilan yang telah memiliki kekuatan hukum tetap.

\section{Kesimpulan}

1. Pelaksanaan fungsi peradilan dan fungsi pengawasan yang dilaksanakan oleh PTUN setelahUUAPdisahkan, mengalami perluasan Perluasan fungsi peradilan yaitu selain memeriksa, memutus dan menyelesaikan sengketa tata usaha negara. juga memutus permohonan yang diajukan Pemohon dengan dasar hukum yang berbeda. Fungsi peradilan mengalami perluasan dengan adanya pengajuan permohonan berdasar Pasal 21, Pasal 53 UU AP dan perluasan makna keputusan tata usaha negara berdasar Pasal 87 UU AP. Fungsi pengawasan yang melekat bersama fungsi peradilan, turut mengalami perluasan. Permohonan berdasar Pasal 53 
UU AP sudah ada, namun jumlahnya tidak sebanyak gugatan pembatalan keputusan tata usaha negara. Agar fungsi peradilan dan fungsi pengawasan oleh PTUN dapat sesuai dengan UU AP, perlu disusun undang-undang baru mengenai PTUN. Upaya harmonisasi perlu dilaksanakan, untuk memberi kepastian hukum bagi masyarakat.

2. Kualitas tata kelola pemerintahan dilihat dari jumlah gugatan yang masuk ke PTUN, AUPB sebagai salah satu syarat materiil pengajuan gugatan sekaligus sebagai batu uji terhadap keputusan tata usaha negara yang digugat. Setelah UU AP disahkan, pengajuan gugatan lebih banyak dibandingkan permohonan Pasal 21, 53 dan gugatan Pasal 87
UU AP. Kurangnya pemahaman mengenai AUPB, kurangnya kemampuan manajerial dalam mengelaborasi AUPB, kurang memahami standar operasional prosedur dalam perundangan terkait, merupakan beberapa faktor yang menyebabkan kualitas tata kelola belum berjalan dengan baik. Untuk meningkatkan kualitas tata kelola Pemerintahan yang baik, perlu sosialisasi arti penting UU AP, pemahaman serta arti penting AUPB dalam penyelenggaraan pemerintahan. Selain itu kemampuan teknis manajerial dalam menjalankan pemerintahan juga harus ditingkatkan.

\section{DAFTAR PUSTAKA}

\section{A. Buku}

Fachruddin, Irfan, 2004, Pengawasan Peradilan Administrasi Terhadap Tindakan Pemerintah, Alumni, Bandung.

Fahmal, H.A.Muin, 2006, Peran Asas-asas Umum Pemerintahan Yang Layak Dalam Mewujudkan Pemerintahan yang Bersih, UII Pres, Yogyakarta.

Manan, Bagir, 2009, Persepsi Masyarakat Mengenai Pengadilan dan Peradilan Yang Baik dalam Menegakkan Hukum Suatu Pencarian, Asosiasi Advokat Indonesia, Jakarta.

Marbun, S.F., 2014, Asas-asas Umum Pemerintahan Yang Layak, FH UII Press Yogyakarta, Yogyakarta.

Muchsan, 2007, Sistem Pengawasan Terhadap Perbuatan Aparat Pemerintah Dan Peradilan Tata Usaha Negara, Liberty, Yogyakarta.

Sinamo, Nomensen, 2016, Hukum Acara Peradilan Tata Usaha Negara, Jala Permata Aksara, Jakarta.

Tjandra, W. Riawan, 2009, Peradilan Tata Usaha Negara Mendorong Terwujudnya Pemerintahan yang Bersih dan Berwibawa, Universitas Atma Jaya Yogyakarta, Yogyakarta.

\section{B. Artikel Jurnal}

Verburg, Andre dan Schueler, Ben, "Procedural Justice in Dutch Administrative Court Proceedings", Utrecht Law Review. Vol. 10. Issue 4 November 2014.

Hubbard, Ruth, "Criteria of Good Governance", Optimum The Journal of Public Management, Vol 30, No. 2.

\section{Artikel dalam Antologi dengan Editor}

Nirwanto, Andhi, "Arah Pemberantasan Korupsi ke Depan) Pasca Undang-undang Administrasi Pemerintahan" dalam Yulius, Ed. H., et al., 2015, Undang-undang Administrasi Pemerintahan Dalam Upaya Pemberantasan Korupsi, Sinar Grafika, Jakarta.

\section{Internet}

British dan Irish Ombudsman Associaton, "Guide to Principles of Good Governance",www. ombudsmanassociation.org/docs/ BIOAGovernanceGuideOct09.pdf, diakses pada Tanggal 20 Maret 2016.

\section{E. Peraturan Perundang-Undangan}


9 Juni 2016.

Undang-Undang Nomor 30 Tahun 2014 tentang Administrasi Pemerintahan (Lembaran Negara Republik Indonesia Tahun 2014 Nomor 292, Tambahan Lembaran Negara Republik Indonesia Nomor 5601).

\section{E. Lain-lain}

Sistem Informasi Penelusuran Perkara di PTUN Semarang, Yogyakarta, Surabaya, Bandung, Jakarta.

Wawancara dengan Ketua PTUN Semarang, tanggal
Wawancara dengan Hakim PTUN: Enrico Simanjuntak, S.H.MH, di PTUN Yogyakarta tanggal 26 Mei 2016.

Wawancara dengan Hakim PTUN: Umar Dani, SH.,MH, di PTUN Yogyakarta tanggal 27 Mei 2016.

Wawancara dengan Hakim PTUN: Andi Muhammad Ali Rahman, S.H.,MH. Hakim PTUN Yogyakarta, tanggal 27 Mei 2016.

Wawancara dengan Hakim PTUN Jakarta Tri Cahya Indra Permana,S.H.M.H, tanggal 18 Juli 2016.

Wawancara dengan Ketua PTUN Surabaya, tanggal 25 Juli 2016.

Wawancara dengan Hakim PTUN Jakarta, Teguh Satya Bhakti, S.H.,MH, tanggal 19 Juli 2016. 